\title{
History of flood fighting in the Kisosansen River Basin
}

\author{
Y. Takeuchi ${ }^{1}$, M. Takezawa ${ }^{2}$ \& H. Gotoh ${ }^{2}$ \\ ${ }^{1}$ Japan Infrastructure Partners, Japan \\ ${ }^{2}$ Civil Engineering of Science \& Tech., Nihon University, Japan
}

\begin{abstract}
The Isewan Typhoon caused considerable damage to the downstream regions of the Kisosansen River Basin on $26^{\text {th }}$ September 1959. It caused approximately 4,500 deaths in and around Nagoya City, the most industrial city in Japan. This study describes the history surrounding the major flood mitigation projects related to land use in the Kisosansen River Basin since 100 A.D. when paddy fields were first established on the alluvial plain. Land use of the area gradually evolved to cover the entire alluvial plain, developing from subsistence farming to modern sophisticated industry. This study shows that economic development in the both side plains of the river has been altered since the construction of the eastern side dike on the Kiso River. The Kisosansen River Basin, with a catchment area of $9,100 \mathrm{~km}^{2}$, is drained by the Kiso River, the Nagara River and the Ibi River. These rivers previously flew in the Nobi Plain as a single river, with successive floods producing a change in the main channel.
\end{abstract}

Keywords: Isewan Typhoon, Kisosansen River, history of flood mitigation works, benefits associated with flood mitigation works.

\section{Introduction}

While flood damage has always been associated with agriculture and human settlement, they have increased in size and frequency as land use has changed for settlement, agriculture, commerce and industry. The Isewan Typhoon affected the downstream regions of the Kisosansen River Basin on September 26, 1959. The extraordinary damage caused by this natural disaster was due to a combination of the natural force of the typhoon itself and the history of human activities in the area. This study describes the history of flood fighting with 
particular emphasis on previous human activity in the Kisosansen River Basin. Finally, this study describes the effect that flood mitigation projects have on both the present capital account of buildings and their property and the accumulation of those accounts by economic development over an extended period in the areas where these mitigation measures have been deployed.

\section{Isewan Typhoon}

The Isewan Typhoon was spawned at $11^{\circ} \mathrm{N} 160^{\circ} \mathrm{E}$ in the South Pacific Ocean on September $20^{\text {th }}$, 1959. It developed into a huge typhoon and proceeded northward to the Isewan in central Japan on the evening of September $26^{\text {th }}$. It moved across the area at a mean velocity of $65 \mathrm{~km} / \mathrm{sec}$ and the barometric pressure at the center of the system was $929 \mathrm{hPa}$ at 18:00 on the day the system landed at Shionomisaki on Honshu Island of Japan. The maximum wind speed of the system, the second largest recorded in Japan when measured using the barometric pressure at the center of the typhoon, measured $60 \mathrm{~m} / \mathrm{sec}$ in Komaki City and the storm zone above $30 \mathrm{~m} / \mathrm{sec}$ had a radius of $300 \mathrm{~km}$. A maximum tide level of $3.89 \mathrm{~m}$ above sea level (ASL) was recorded in Nagoya Port. The wave was 3 to $4 \mathrm{~m}$ high, meaning that floodwaters would have been in excess of $7 \mathrm{~m}$ ASL at the Kisosansen River estuary.

Based on these records, the crown of coastal dikes was reconstructed $7.50 \mathrm{~m}$ high ASL for the sea flood around the Isewan. The crown height of dikes was decided based on records of Isewan Typhoon and the probability of one in fivehundred year floods. The coastal dikes along the Kisosanse Estuary had moved 10 to $15 \mathrm{~km}$ towards the sea as land reclamation had progressed over the 360 year period from 1600 to 1959 . The Isewan Typhoon breached these dikes at several locations in 1959 resulting in the most severe damage to date due to inundation by water from the sea. The typhoon illustrated the vulnerability of the area to flooding by the sea.

The separation works of the three main channels in the Kisosansen River, the Kiso River, the Nagara River and the Ibi River, were completed in the 1910s. Since no flooding subsequently occurred there, and given the sense of trust that local inhabitants placed in the dikes, most households dispensed of the lifeboats that they had hung under the eaves of their houses. In addition, people migrated from the highlands and started building their houses in the wetland areas. The coastal dike along the Isawan, or the Ise Bay, had been constructed to a height of 5 to $6 \mathrm{~m}$ ASL on the experience of the typhoon in 1953. It means that more than a $2 \mathrm{~m}$ high flood water flowed over the dike of $5 \mathrm{~m}$ ASL. While sea-facing slope of the dikes were covered with concrete, the other landward-side slope was constructed only of soil. At the time of flooding, the floodwaters flowed over scouring out the soil of the landward-side, which eventually collapsed. The ensuing floodwaters inundated towns, villages, and farmlands in the total darkness when their electric supply had been stopped. The storm surge inundated Kuwana City and Nagashima located in the Kisosansen estuary, as well as Nabeta Reclamation Village and the southernmost parts of Nagoya City in a sea of muddy water. 
The seawater submerged a 31,000 ha of land and reached Tsusima City some $15 \mathrm{~km}$ distant from the coast. Pools remained for two months and the life of inhabitants decreased markedly. The primary damage caused by the Typhoon was 4,487 fatalities, 32,629 collapsed houses, 5,220 washed-out bridges, $131,129 \mathrm{~m}^{3}$ of washed-out lumber, and 1,064 sunken boats [1,2].

\section{History of flood fighting in the Kisosansen River Basin}

Paddy cultivation is thought to have been introduced into Japan from China approximately 6,400 years ago [3]. Originally, rice was planted in areas that were safe from floods, but as paddy fields expanded into areas of arable wetland, the potential risk of flood damage increased markedly. In Shizuoka City, Japanese inhabitants had been cropping rice at the Toro Relic in about A.D. 100, as well as in the downstream basin of the Kisosansen Basin approximately $170 \mathrm{~km}$ away. However, flooding in the wetlands prompted local inhabitants to develop a variety of flood mitigation measures in the Kisosansen Basin.

\subsection{Primitive flood fighting}

Initially, when wetlands started being used by local inhabitants, the defense methods against floods were relatively primitive and based on instinct. One such method was the use ground that was more elevated than the surrounding area, and another method was planting trees around houses to decrease the fast flowing flood waters [2].

\subsection{Individual flood fighting methods}

It is not clear when people in this region first began using flood fighting methods. This method of flood mitigation is still in use and is referred to as Mizuya in Japanese, or 'water cottage' in English. The first Mizuya was constructed with ceilings made from strong board like a floor. At the time of floods, the family could then take refuse in the attic of their houses. Attics were made to float during high water and the members of the household were able to cook and live there until the water subsided [2, 4].

When the Isewan Typhoon occurred, the people who lived in such attics were able to escape the disaster. "Mizuya" was a strong house against flood like a two or three-storied warehouse on high ground which was made of piled up stones; such structures remain today. Based on this idea, reinforced concrete houses were recommended for construction after the Isewan Typhoon. They have a workroom on the first floor, living room on the second floor, and place for shelter on the third floor. However, these houses were inconvenient to live in and they have disappeared gradually over time [2]. Nonetheless, they are still recommended in the downstream areas of the Kisosansen River and the Sinano River basins in Japan [5]. 


\subsection{Collective flood fighting using ring dikes}

All of the land on the island of Japan was appropriated by the state in 645 . In 743, after approximately one hundred years, the area of farmland to distribute among the increasing population gave out, and the land law on reclaimed land to enter into possession of its pioneer was issued. This had the effect of creating a powerful landowning class consisting of families with considerable financial power. These families constructed large dikes for themselves to protect their lands against floods. At the time, they did not have the technical or economic prowess to construct long, continuous dikes along large rivers. Instead, they constructed ring-shaped dikes that were not completely closed. The upstreamside was closed to protect the land within from powerful floods and the downstream side was opened to allow for the drainage of any water that did manage to enter the dike. As the development of wetlands spread, these incomplete ringtype dikes became increasingly ineffective against floods and storm surges. The representatives of nineteen villages in the lower reaches of the Kisaoansen River in Gifu Prefecture gathered to discuss these countermeasures in 1319. The outcome of the meeting was that the downstream side of the incomplete-ring dike should be closed by a cofferdam measuring approximately $2 \mathrm{~m}$ in height $[2,4]$.

\subsection{Regional flood fighting by the construction of a continuous dike}

Taiko Hideyoshi brought all Japan under his control in 1590. He initiated the development of a large-scale flood mitigation project in the Kisosansen River Basin where he was born. There was a big flood there in 1586, which caused considerable damage and altered the river channel. He adopted the development of large-scale civil engineering works as the policy of a prosperous country. Works started in 1592, and in three years, a $260 \mathrm{~km}$-long system of dikes with 50 $\mathrm{km}$ along both sides of the main channel from Inuyama to the estuary on the Kiso River including the branches was constructed. Compared to present dikes, the structure of the dikes in those days were very poor. However, the construction of such long dikes over such a large area was a tremendous achievement at the time. The dikes moderated the turbulent flow in the rivers and promoted the runoff of floodwaters into the sea. But the power of flood flows against the dikes became stronger by the control of channel.

After the death of Hideyoshi, the Shogun Tokugawa Ieyasu won a battle at Sekigahara in 1600, after which he reunified the nation and opened the Edo regime. The occurrence of a flood disaster of the previous year resulted in the Shogun ordering the closure of several channels of the main river branches and anabranches in 1607 so that a continuous dike could be constructed on the Kiso River. However, in doing so, farmers could not gain access to water for irrigation. The farmers suffered severely and eventually broke the dikes so that they could abstract irrigation water from the river. Unfortunately, the area experience considerable rainfall in the beginning of October and the dike along the Kiso River was breached for $1,000 \mathrm{~m}$, which resulted in the flooding of extensive areas in the eastern catchment area. During two years following 1608, the 
Tokugawa Shogunate constructed a stronger dike that extended $50 \mathrm{~km}$ from Inuyama to the estuary on the main channel. Such a large dike, which measured $9.1 \mathrm{~m}$ to $14.5 \mathrm{~m}$ above ground level, had never been seen previously in the region. In addition to serving as a flood control measure it also served as a rampart from which to protect the area from the enemy to the west. Roads that were $14.5 \mathrm{~m}$ to $18.2 \mathrm{~m}$ wide to strength dikes and to move troops were constructed on the crowns of the dikes $[2,4]$.

\subsection{Afforestation for flood control}

The upper river reaches of the Kiso River have a steep gradient and the river has a total length of $150 \mathrm{~km}$ from the headwaters at 3,000 m high ASL to the sea. The annual average rainfall is $2,500 \mathrm{~mm}$ in the upper river reaches and 1,600 $\mathrm{mm}$ on the floodplain below. Taken together, these factors make it difficult to maintain the river channels because of sediment deposition in the plain region where the land is densely populated. Strict regulations directed at the conservation of forest areas were therefore promulgated in 1665. The Owari clan, one of the families of the Tokugawa Shogunate appropriated $70 \%$ of the $4,700 \mathrm{~km}^{2}$ mountainous area of the Kiso River Basin for purposes of flood mitigation in the plain region and to ensure the supply of wood for building material. The Owari clan also forbade inhabitants of the mountain regions from entering the forest and from felling trees. If someone was found to have broken the law, their village would be punished collectively by death; death was by decapitation and one head for one tree. This punishment had been taken over until the Meiji Restoration [2, 4].

\subsection{Separation of three rivers}

Constructed of the strong continuous dike on the eastern side of the Kiso River in 1608, meant that more floodwater would accumulate on the opposite side and also that the flow of the water would be increased due to the closing its branches. The eastern dike of the Kiso River was $0.9 \mathrm{~m}$ higher than the western one. In addition, the riverbed of the Ibi River was the lowest in the Kisosansen Basin and the Kiso River was the highest. Floodwater levels increased, spilling over from the Kiso River into the Nagara River and then into the lowest river, the Ibi River, at the estuary. In addition, the increased floodwater at the estuary of the Ibi River made the backwater of the three rivers higher and flooded in the middle reaches of western side of Kisosansen Basin and their inhabitants experienced serious flood disasters almost every year. Before 1608, there was no economic disparity between the people in the eastern areas of what had become the Kisosansen Basin and the basin on the opposite side of Gifu Prefecture. However, the inhabitants of the western basin became increasing poor thereafter.

Izawa Tamenaga, who was the local governor of Mino County in 1735-1737, saw the misery of the people. Consequently, undertook an accurate field investigation in the Kisosansen and developed a plan to separate the meandering Kisosansen into three river channel. He proposed the plan to members of the 
cabinet of the Tokugawa Shogunate in Tokyo; however, they did not implement it immediately.

Works on separating the river to three channels started finally in 1748 , in response to repeated petitions from people in 1743 and 1746. The Tokugawa Shogunate excavated the estuary shore on the Ibi River to increase the discharge capacity into the sea at which the flood water gathered. They constructed two spur dykes in the Kiso River to increase the inflow into the Saya River and to reduce the water flowing into the combined river of the Kiso River and the Nagara River. The Saya River was formed from the eastern branch of the Kiso River. However, the riverbed of the Saya was more elevated than that of the main channel of the Kiso River, which inhibited flow in the Saya River.

Ring dikes in the wetlands were not able to effectively prevent flood disasters, even after the previous works were conducted, which meant that farmers still had poor consecutive harvests. The inhabitants of the area petitioned the central government to address the risk affecting their lives, even though public demonstrations such a nature was forbidden at the time. In the middle of August in 1753, just as the Tokugawa Shogunate was undertaking plans for large-scale river improvements to alleviate the need for the people in ring dikes, extensive flooding of the area occurred and floodwaters rushed into the ring dikes. After investigating the extent of the damage in September and October, on December 25 in the Horeki era the Shogunate ordered Satsuma clan, one of the greatest feudal lords of at the southern edge of Kyushu Island, to implement flood mitigation measures; the event is one of most famous historical events in Japan. These works had a political purpose to weaken the military power of Satsuma clan with the enormous costs of the project. The Tokugawa Shogunate supervised the work so strictly that 51 of the 1,000 samurai from Satsuma clan working in the project committed hara-kiri in protest. Hirata Yukie, the head of the project, also committed hara-kiri and accepted all of the responsibility for the families of victims and the lord at the end of the works.

The work was divided into the post-disaster restoration works, and the initiative separation works as follows:

(1) Construction of a $15 \mathrm{~km}$-long continuous dike on the western side of the Kiso

River, between $40 \mathrm{~km}$ distance at Kasamatu and $25 \mathrm{~km}$ distance at the confluence of the Kiso River and the Nagara River from the present river mouth. But the crown of the western side dikes was obliged to be $0.9 \mathrm{~m}$ lower than the opposite side because of the strong political power of the eastern side plain.

(2) Construction of two spur dikes on the Kiso River at the point where the Saya River branched off the Kiso River.

These two projects increased the inflow from the Kiso River to the Saya River and decreased the inflow from the Kiso River to the Nagara and Ibi rivers.

(3) Construction of a cofferdam on the Kiso River at the confluence of the Gyaku River, which blocked the inflow of the Kiso River to the Nagara River. 
(4) Construction of a cofferdam on the Nagara River at the confluence with the Ogure River, which blocked the inflow from the Nagara River to the Ibi River.

(5) Construction of an interlocking dike.

The latter three works for separating the Kiso and Nagara rivers were difficult; especially the construction of the interlocking dike. When the Ibi River was separated perfectly from the other two rivers at the confluence of three rivers with a $2 \mathrm{~km}$ wide channel, the Ibi River was complete. However, the western side of the dike of the combined Kiso-Nagara River was not able to handle the increased discharge, which meant that some of the peak discharge in the combined river flowed into the Ibi River. Consequently, an interlocking dike composed of two spur dikes was designed to cope with these two problems. One dike was a large spur dike measuring approximately $1 \mathrm{~km}$ in length from Aburajima to the lower river reaches, which bifurcated into two dikes from the end like two extended monkey tails. To decrease the force of floodwater, one bifurcated dike intercepted the flood discharge in the combined river of the KisoNagara River, while the other intercepted the flood discharge in the Ibi River. The other 360-m-long spur dike was stretched out from Matsunoki and extended to the middle section of the upper reaches of the river. The interlocking dike had a $400 \mathrm{~m}$ long space between the two spur dikes, which were designed to weaken the force of flood discharge that passed between them and also to decrease the flood discharge between them $[2,4]$.

\subsection{Modern engineering works}

The new government of the Meiji Restoration was established in 1868. The government motto was "prosperous country and strong army". As a part of implementing this policy, the government decided to conduct large civil engineering works to assist the people in the ring dikes of the western basin of the Kisosansen. This was in response to a series of floods that occurred from the 1860 s to 1880 s.

The new central government dispatched a Dutch civil engineer named Johannes de Rijke to the site to oversee the river improvements in 1878. De Rijke came to Japan in 1873, and although his sister died after six years after their arrival without having the benefit of his nursing-care, he remained in Japan for thirty years. During his stay in Japan, he drafted a river improvement plan on the Kisosansen River and designed the foundation of river improvement works. After his detail field surveys, Mr. de Rijke found that the main cause of flooding was attributed to the deposition of sediments and the concomitant decrease in the discharge capacity of the river channels. He designed a river improvement project incorporating meandering and bifurcated channels into the main channels to flow down floodwaters smoothly. Of particular interest was his plan to separate the Kiso River to make single channel. The purpose was therefore to separate the Kiso River from other two rivers by excavating a new river channel and constructing a new 12-km dike between Naruto and Sendohira to separate the Kiso and Nagara rivers, and also to reconstruct the interlocking dike at 
Aburjima. The Nakamura River and the Ogure River, which joined the Nagara River to the Ibi River, were closed completely - not only to block off the floodwater to the Ibi River, but also to decrease the influence of back water on the upstream reaches and to discharge floodwater into the sea quickly. In addition, they constructed a cofferdam at the entrance of the Saya River and a training dike to guide floodwaters from the Kiso River to the sea. Furthermore, he proposed the afforestation of the mountainous areas for erosion control to decrease the transport of sediments and the ensuing decreased flow capacity of the streams and main channels.

Mr. de Rijke devised the necessary changes to the system by applying modern hydraulic mechanics to the results of the field survey. The government initiated river improvement works in the Kisosansen from 1887 as a project that would take sixteen years to complete. In that time numerous crises occurred, including the big Nobi earthquake of 1891, the Sino-Japanese War from 1894 to 1895 , and the Russo-Japanese War between 1904 and 1905. These works were finally completed in 1912, twenty-five years after works on them were started.

After completion of the works, the ring dikes that had been used for hundreds of years had become useless and obstructive. From then, entire Nobi plains region did not incur any damage due to large floods until the damage that was caused by the large storm $1959[2,4]$.

\subsection{Dam construction}

The Ooi Dam was constructed on the Kiso River in 1923 and is still currently in use today. It was the first high concrete gravity dam in Japan as well as being a hydroelectric power dam with a reservoir. The dam is $53 \mathrm{~m}$ high and $275 \mathrm{~m}$ long. At the time, it was very difficult to construct such a high dam on the Kiso River, which had a large peak discharge when flooding. The Maruyama Dam is a multipurpose dam intended for flood control and water utilization. The dam was constructed on the Kiso River in 1954. It is a concrete gravity dam, measuring $98.2 \mathrm{~m}$ high and $260 \mathrm{~m}$ long. Its effective storage capacity is $38 \times 10^{6} \mathrm{~m}^{3}$ and its flood control capacity is $20 \times 10^{6} \mathrm{~m}^{3}$. In addition to the classic method of using long continuous dikes to channel floodwaters to the sea as quickly as possible, a new method employing large dams to decrease peak flood discharges and reduce the load of river channels was thus employed in the Kiso River Basin. Today, Maruyama Dam, Yokoyama Dam, Iwaya Dam, Akigawa Dam, Misogawa Dam have all been constructed on the Kisosansen River and Tokuyama Dam - a multipurpose dam serving both as flood control and water utilization - is almost completed. The total flood control capacity of these dams is $243 \times 10^{6} \mathrm{~m}^{3}[2,6]$.

\subsection{Estuary Dam}

After World War II, related the development of the Chukyo Industrial Zone, the land use of the Nobi plain in the lower river reaches of the Kisosansen River changed from paddy fields to housing and industrial areas. In addition, the development of river improvements and agricultural drainage works in the upper river reaches, combined with development of sewerage works in the urban areas, 
has the effect of making runoff faster from the basin when it rains. Consequently, peak discharge in river channels during floods has increased progressively compared to previous years with the same rainfall. In addition, in the areas around and near the dikes in the Nobi plain, housing density had increased markedly. Importantly, it had become increasingly difficult to increase the discharge capacity in the channels by raising dikes, or by setting dikes back. To resolve this problem, extensive dredging of the riverbed was planned to increase the discharge capacity in the channel. If riverbeds of the channel in a wetland area adjacent to the sea are excavated, salty water will intrude into the channel. Such intrusion makes municipal water more expensive to treat and has a negative effect on paddy cultivation. To prevent saltwater intrusion into the Nagara River, an estuary dam was constructed $5.4 \mathrm{~km}$ from the sea in 1995 to maintain the water level above $2.20 \mathrm{~m}$ ASL on the upper reaches from the dam. Construction of the estuary dam made it possible to take the more water by $22.5 \mathrm{~m}^{3} / \mathrm{sec}$ for municipal use. The dam is $661 \mathrm{~m}$ long at its total length [2].

\section{Economic effects associated with the flood mitigation works}

The Shogunate constructed a $50 \mathrm{~km}$-long dike on the eastern dike of the Kiso River from Inuyama to Yatomi in 1610. Consequently, the height of the crown on the eastern dike was $0.9 \mathrm{~m}$ higher than that of the western one for approximately 280 years until 1887 . For almost 400 years since 1610 , there had not been a flood on the eastern side of the Kiso River plain, while many floods have occurred on the western side plain.

Before 1610 , both of the plains were closely connected with the river and their natural, social and economic conditions were almost identical. However, economic development in the plains had differed since the construction of the eastern side dike. In the Bisai District of Aichi Prefecture, in addition to the existing silk textiles, cotton textiles had been produced on the eastern side plain from the early $17^{\text {th }}$ to $19^{\text {th }}$ centuries. As these textile industries developed, engineering activities and capital accumulation facilitated the production of high quality wool textiles, and the industrial infrastructure necessary to produce weapons, cars and aircraft throughout the prefecture until the 1920s. In 1999, industrial production per capita in Aichi Prefecture on the eastern side plain was valued at 1,960 thousand yen per annum and that of Gifu Prefecture on the western side plain at 96 thousand yen per annum. This difference in industrial production per capita between the two prefectures is considered to be influenced by the difference in the difference in crown height between both sides of dike.

The Government analyzed differences in flood damage in the flood susceptible areas of the Kiso River Basin between Aichi Prefecture on the eastern side plain and the Gifu Prefecture in the western side plain in 1953. The people of Aichi Prefecture had more domestic property than those in Gifu Prefecture. When the indicators included industrial and agricultural properties and products, the difference in economic prosperity between the two prefectures would be even more apparent. The economic benefits associated with flood mitigation were qualitatively demonstrated in a case study of the eastern dike of 
the Kiso River, where more expensive properties were protected against floods and generated new capital [7].

\section{Conclusions}

Unless we came close to the water without fear for paddy cultivation, we would never have a flood disaster. Flood mitigation works have always been conducted after flood disasters, so much so that the history of flood mitigation works mirror that of flood disasters. While we have altered our land use patterns repeatedly since ancient times, we have not been able to keep up with our life mode and soft ware for flood fighting changed by our land use. The more land use habits change without any regard for the surrounding environment, the greater the danger associated with flooding increases.

Numerous flood mitigation projects for alluvial basins around the world have not been implemented because of problems associated with the economic analyses related to such projects or their engineering measures. However if the economic effect as shown in the Kiso River Improvement Project case study from the early $17^{\text {th }}$ century is assessed in addition to the existing economic evaluation of the direct and indirect damage by flood, it give a project more economic feasibility. Economic prosperity can thus be realized through the benefits of capital accumulation due to the construction of flood mitigation infrastructure in the long term, which has enabled subsequent investment in new industrial projects.

\section{References}

[1] Bureau of Chubu Regional Construction, Ministry of Construction, Postdisaster restoration works of the Isewan Typhoon, vol.1, pp. 73-75, 205, Nagoya, Japan, 1963.

[2] Yoichi, T. The Kisosansen, pp.31-49, Proceedings of a Seminar on ESCAPE and Typhoon Committee in Tokyo, 1976.

[3] Yoichiro, T., History of rice paddies in Japan, pp. 23, 64-66, Kadokawa shoten, Tokyo, 2002.

[4] Asahi Shimbun, Kiso River, caption 29, 53, 81, 86, 96, 100, 101, 102, Tokyo, Japan, 1961.

[5] Tokyo Shinbun, Ancient knowledge for flood control, January $8^{\text {th }}$ pp. 1 , Tokyo, Japan, 2008.

[6] Bureau of Chubu Regional Construction, Ministry of Construction, Kisosansen, pp.716, Nagoya, Japan, 1988.

[7] Yoichi, T. \& Mitsuo, T., Flood mitigation planning related to land use, River Flow 2004, Proceeding of the Second International Conference on Fluvial Hydraulics, Napoli, Italy, vol.2, pp.1421-1427, 2004. 